\title{
Ömer Seyfettin'in Hikâyelerinde İroni İle İnşa Edilen Eleştirel Söylem: Cehalete Dayanan Halk İnanışları
}

\author{
Hakan DEĞİRMENCI $\dot{I}^{1}$
}

Öz

1884’te Balıkesir/Gönen'de dünyaya gelen Ömer Seyfettin, İstanbul'da askeri eğitim görmüş, daha sonra Makedonya, Selanik ve İzmir'de görev yapmış bir askerdir. Görevi gereği hem devletin başkentinde hem Anadolu'da hem de döneminde ülkenin siyasi ve etnik olarak en çalkantılı olaylarına sahne olan Balkanlar'da bulunmuş, bu esnada sadece cepheyi değil, cephe gerisini de tanıma ve anlama fırsatı bulmuştur. Yazar, böylesine geniş ve kritik bir coğrafyada müşahede ettiklerini, sanatçı fitratında var olan canlı ve hassas bir eleştiri gücüyle süzgeçten geçirmiş ve bir sosyolog edasıyla bunları hikâyelerinde işlemiştir. Çarşıyı pazarı, camiyi, tekkeyi, mahalleleri, ücra ve tenha yerlerdeki küçük hayatları, evleri ve avluları, tarlaları ve tarım işçilerini, devlet dairelerini gezmiş, hikâyelerinde buradaki hayatlara ayna tutmuştur. Anlatılarında sadece bununla yetinmemiş, olup biteni akıl-bilim-vicdan eleğinden geçirerek tartışmış, didaktik ve ahlakçı bir tavır sergilemiştir. Ömer Seyfettin nesrinin en dikkat çeken tarafı hiç kuşkusuz ironidir. Hikâyelerinin ekseriyetini teşkil eden tarihsel hikâyelerinde dahi gördüğümüz bu hususiyet, toplumsal meseleleri ele aldığı hikâyelerinde zirveye çıkmakta, özellikle halk inanışlarındaki hurafelerin ele alındığı, türbe, muska, büyü gibi imgelerin öne çıktı̆̆ı, cehaletin doğurduğu sonuçların işlendiği hikâyelerde ironik anlatım daha da göze çarpmaktadır. Çalışmamızda Ömer Seyfettin'in öykülerinde cehaletle savaşını metinlerden örneklerle gözler önüne serip sosyolojik, teolojik ve pedagojik tahlillerle meseleyi kavramaya çalışacağız.

Anabtar Kelimeler: Ömer Seyfettin, Hikâye, Toplum, Cehalet, İroni

\section{Critical Discourse Built with Irony in Ömer Seyfettin's Stories: Public Beliefs Based On Ignorance}

\begin{abstract}
Ömer Seyfettin, who was born in Balıkesir Gönen in 1884, is a soldier who received military training in Istanbul and later served in Macedonia, Thessaloniki and Izmir. As a result of his duty, he was found in the capital of the state, in Anatolia and in the Balkans, where he witnessed the country's most politically and ethnically turbulent events and he had the opportunity to get to know and understand not only the front but also the rear. The author filtered what he observed in such a wide and critical geography with the vivid and sensitive power of criticism that exists in the artist's nature, and processed them in his stories with the style of a sociologist. He visited the bazaar market, mosque, the dervish lodge, neighborhoods, small lives in remote and secluded places, houses and courtyards, fields and agricultural workers, government offices, and in his stories he reflected the lives here., he was not only satisfied with this, he discussed what was going on through the mind-science-conscience sieve, and showed a didactic and moralist attitude. The most striking aspect of Ömer Seyfettin prose is undoubtedly irony. This feature, which we have seen even in the historical stories that constitute the majority of their stories, reaches the top in their stories dealing with social issues, especially in the stories where the superstitions in folk beliefs are discussed, and images such as tombs, amulets and magic come to the fore and ironic narration is more prominent. In our study, we will try to grasp the issue with sociological, theological and pedagogical analyzes by revealing the fight against ignorance in Ömer Seyfettin's stories with examples from the texts.
\end{abstract}

Key Words: Ömer Seyfettin, Narrative, society, Ignorance, Irony

\section{Atıf İçin / Please Cite As:}

Değirmenci, H. (2021). Ömer Seyfettin'in hikâyelerinde ironi ile inşa edilen eleştirel söylem: Cehalete dayanan halk inanışları. Manas Sosyal Araștirmalar Dergisi, 10(1), 17-26.

Geliş Tarihi / Received Date: 13.02.2020

Kabul Tarihi / Accepted Date: 31.10.2020

\footnotetext{
${ }^{1}$ Dr. - Aydın Adnan Menderes Üniversitesi Eğitim Fakültesi, hakan.degirmenci@adu.edu.tr 


\section{Giriş}

1884-1920 yılları arasında yaşamış olan Ömer Seyfettin, edebiyatın birçok türünde eser vermiş bir sanatçıdır. Sanatçilığının yanı sıra Türkçülüğün ve dilde sadeleşme hareketlerinin önderlerinden olması bakımından bir Türkolog ve teorisyendir. Ömer Seyfettin, "milli hikâyeci" olarak milli şair Mehmet Akif in şiirde yaptığını nesirde yapmıştır. Nitekim her ikisi de Abdülhamit döneminden itibaren yaşanan birçok siyasi ve askeri krizleri, ekonomik koşulların ağırlaşmasını ve bunlara paralel olarak git gide artan toplumsal sorunları bizzat görmüş, yaşamış ve bir aydın hassasiyetiyle bunları sanat eserleri vasıtasıyla dile getirmişlerdir. Ömer Seyfettin bunlara ilaveten asker olması sebebiyle yıllarca cephede bulunmuş, böylelikle hem Anadolu'yu hem Balkan coğrafyasını görmek ve mukayeseli çıkarımlar yapma imkânı bulmuştur.

Ömer Seyfettin, kısacık hayatında birbirinden kıymetli, yüz elliden fazla hikâye kaleme almıştır. Bunları konuları bakımından birkaç kümede toplamak mümkündür: Bunlardan ilki ve sayıca en fazla olanı tarihî hikâyeleridir. Bu türden hikâyelerini konularını tarihten alanlar ile aktüel zamandan alanlar diye ikiye ayırarak inceleyebiliriz. Ardından birbirine yakın sayılarda çocukluk dönemi hikâyeleri, kadın, aşk ve evlilik meselelerinin işlendiği hikâyeler ve -bu çalışmamızın konusu olan- toplumsal meselelerin ele alındığ1 hikâyeler gelmektedir.

Enginün'ün de ifade ettiği gibi (2012, s. 8) yazar, bir kısmı inanılamayacak kadar ac1 ve sert olan yaşantılarını hikâyelerine yansıtmışıtı. Enginün bir başka eserinde (2006, s. 437) yazarın amacının topluma "ahlâkî dersler" vermek olduğunun altını çizmiştir. Polat ise (2007, s. 81) bu hikâyeleri Ziya Gökalp'in düşünceleri doğrultusunda kurulan Halka Doğru Cemiyeti'nin misyonuyla irtibatlandırır. Hasilı sanatı toplum için yapılan bir faaliyet olarak gören ve realizm akımını benimsemiş olan Ömer Seyfettin, edebiyat tarihçilerinin "Maupasant tarzı hikâyecilik" olarak kavramsallaştırdığı "olaya dayalı anlatımı"yla dönemine ayna tutmuştur.

Ömer Seyfettin'in şïrlerinde ve hikâyelerinde halk edebiyatının da büyük tesirleri olduğunu biliyoruz (Filizok, 1984, s. 116). Yazar, çocukluk ve gençlik döneminde çevresinden dinlediği halk anlatılarını hikâye formatında yeniden anlatmıştır (Kılınç, 2007, s. 217). Nitekim bazı hikâyeleri fikralara, efsanelere ve menkıbelere dayanmaktadır.

Yazarın hikâyelerinde dikkat çeken bir husus da muhtevaya ilişkindir. Hikâyelerde kullanılan dil ve üslup özellikleri ile anlatıma dair tercihler üzerinde de durmak gerekir. Sevük'e göre (1935, s. 430) Ömer Seyfettin'in küçük hikâyecilik sahasında şiarı "edebiyatsız edebiyat yapmak"tır; hikâyelerinin mevzuu ve ifadesi açık, tasvirleri kısa, vakaları canlı ve hareketlidir. Aynı şekilde Cevdet Kudret de onun dilinin süssüz, açık ve yalın olduğuna vurgu yaparak, bu dilin 'edebiyat yapmak' olarak adlandırılan şairanelikten uzak olduğunu söyler. (Kudret, 2016, s. 343) Bu durum yazarın hem topluma ulaşmasını kolaylaştırmış, hem de toplum tarafından okunup anlaşılmasına olanak vermiştir. Böylelikle Ömer Seyfettin, yalın bir Türkçe ile öykü yazılabileceğini, halkın dilini ve konuşma biçimlerini kullanarak sağlam öyküler yazılabileceğini de göstermiştir (Uyguner, 1990, s. 39).

Kendi içinde tutarlı ve bütüncül bir dünya görüşü ile Ömer Seyfettin'in aynı zamanda bir teklif niteliği taşıyan, açık ve gizli imalarla çözüm önerileri de sunan politik bir tavır geliştirdiği eserleri, toplumsal nitelikli bir eleştiriye yaslanır (Baş, 2019, s. 202). Yazarın sosyal meseleleri ele aldığı hikâyelerinde dikkat çeken en önemli husus anlatım tekniği ile ilgili olandır. Ömer Seyfettin, toplumsal meselleri ele aldı̆̆1 hikâyelerinde Argunşah'a göre (2012, s. 26) bilgisizlik ve taassup karşısında çoğu zaman mizah ile genişletilmiş bir hicvi tercih etmiştir. Yazar, zaman zaman kahramanların gülünç durumları üzerinden toplumsal hayatın eleştirisini yaparken "hicivci" bir üslupla toplumu iğnelemekten de kaçınmamıştır (Banarll, 1998, s. 1104). Öyle ki onun hikâyelerinin önemli bir kısmında ironi, diğer özellikleri ikinci plana atacak kadar belirgindir (Polat, 2019, s. 25). Onun bu husustaki tavrını Yöntem şöyle ifade etmektedir:

Ömer Seyfettin mizaba meyyâldi, fakat onun mizâhı ac bir ta'riz veya hafif bir fiske șeklinde değildi. Cok kere mübâlağacı ara sira çlgin bir garâbet mabiyetinde idi. Bunu bikâyelerindeki șabıslarda pek bâriz görürǚ. Her müstesna yaratılmıs adam gibi onun da 'belâhet'e karssı bir gį̨li kini vard. Fakat müsâmahakârdı. Budalalara, budalahklara çok kere kızmazdr. Alay ederdi. Şüphesiz hamâkata karşı alay zẹkânn bir bakkııdr. Bu eserlerinde görünür. (Yöntem, 1995, s. 344) 
Yöntem, başka bir eserinde (1993, s. 29) Ömer Seyfettin için mizahın bir yaratılış ve mizaç olduğunu, onun yalnız yazarken değil, konuşurken bile hayata, şahıslara fantezi ile baktığını belirtir. "Benim deham komiktir." (Ünaydın, 2010, s.191) diyen yazar için ironi bir sevk-i tabiidir. ${ }^{2}$

\section{Ömer Seyfettin Kurgusunda İroni ile İnşa Edilen Eleştirel Söylem: Hurafelere ve Cehalete Dayanan Halk İnanışları ${ }^{3}$}

Ömer Seyfettin muhtelif dönemlerde kaleme aldığı makalelerinde Türklük meselesinin yanı başında İslam ve din konularını da yoğun bir biçimde işlemiştir. Ona göre din, milliyet fikrinin belirleyici ve koruyucu unsurlarındandır. Bu anlamda milli varlı̆g koruyan, devleti ayakta tutan önemli bir müessesedir. Toplumsal anlamda kolektif şuuru tesis eden önemli faktördür. Din, bireysel ve toplumsal hayatı doğruya ve güzel olana göre tanzim eder. Aklı ve vicdanı harekete geçirir.

Muharrir, sayıları yüz elliyi aşan öyküleri arasında İslam’ı gerçek anlamda idrak etmiş kişilere de yer vermiştir. ${ }^{4}$ Beyaz Lale, Başım Vermeyen Sebit, Mehdi, Illk Namaz öykülerinde ideal Müslümanlara rastlanmaktadır. Pembe İncili Kaftan hikâyesindeki Muhsin Çelebi bahsini ettiğimiz dindar tipinin en güzel örneği olmalıdır. Varlıklı bir insandır, vaktini ilimle geçirmektedir. Dindardır ama cahil değildir. "Din ve millet aşkını kalbinden duyan" Muhsin Çelebi, padişah tarafindan Tebriz’e elçi olarak gönderilir ve canı pahasına Türklüğün şerefini en iyi şekilde temsil eder.

Diğer taraftan Ömer Seyfettin'in pek çok hikâyesinde hurafelere dayanan halk inanışlarına eleştiri getirilmektedir. Türbe ve Keramet hikâyelerinde türbeler üzerinden, Perili Kösk hikâyesinde periler ve cinler hakkında, Kurbağa Duası ve Pireler hikâyelerinde nefes-üfürük ve fal bakma meselesiyle ilgili, Külah, Çakmak ve Pireler'de halkı din üzerinden kandıran dolandırıcilara ve Deve, Binecek Şey, Hatiften Bir Sala, Tos! ve Beynamaz hikâyelerinde ise İslam idraki problemli olan ve bu yüzden topluma kötü örnek teşkil eden din adamına eleştiri getirilmiştir. Bunlardan Türbe, Perili Köşk, Keramet ve Kurbağa Duası, olay ironisinin en etkili biçimde kullanılması ve sürprizle bitmeleri bakımından, çalışmamız açısından ayrıca önem taşıyan hikâyelerdir.

Türbe hikâyesinde, üfürükçü Şefika Molla’nın içine düştüğü komik durum üzerinden bir hurafe eleştirisi yapılır. Şefika Molla, Selanik'in kuzeyinde yaşayan, iaşesini hastalara okuyup "kurşun dökmek"le kazanan, bir zaman sonra da bu yolla oldukça zengin olan bir kadındır. Zira bütün Selanik'in hastaları ona gelmektedir. "Kısmet için genç kızlar, imtihana yakın zihinleri açmak için mektepliler, çocuğu olmayan kısır kadınlar, kazanamayan tüccarlar, her şeyini kaybetmiş efendiler, kocalarını kıskanan hanımlar, sevgililerine kavuşamayan aşıklar, tezkere alamayan askerler, terfi edemeyen zabitler, vereminden tutunuz, frengisine, belsoğukluğuna kadar her türlü hastalar, kötürümler, körler, dilsizler, sağırlar” (Seyfettin, 2014, s. 215-216) ona okutmakta, muska yazdırmakta, üzerlerine kurşun döktürüp ondan şifa beklemektedirler. Kocasını kaybetmiş ve bir hizmetçisiyle yaşayan Şefika Molla, günün birinde hasta bir arkadaşına ziyarete gitmek zorunda kalır. Otuz senedir ilk defa sokağa çıkacak olmanın verdiği tedirginlikle evden çıkarken Ayetelkürsi'yi, Tüncina'yı, uzunca bir yangın ve hırsız duası okur. Selanik'in aşağı mahallelerine ve deniz kenarında Beyaz Kule taraflarına varınca korkuları, yerini hayal kırıklı̆ına bırakır. Her yer asrileşmiş, “öküzsüz şeytan arabaları”na benzeyen tramvaylarla dolmuş, kadınlar yarı çılak gezmektedir. Nihayet dünya batacak diye düşünürken ileride "küçük kubbesi ve yeşil pencereleriyle" bir türbe görür. İhtiramla oraya yürürken dualar okur ve orda hangi evliyanın yattığını düşünür. Çok mesuttur. Ne var ki içeri girmeye çalıştı̆̆ yer, bir umumi tuvalettir.

Molla Şefika'nın küçük ve hurafelerle dolu dünyası kendini sorgulamak zorundadır. Aksi halde onun inandığ1 ve yaşattığı din telakkisi, hayatın hakikatleri karşısında küçük düşmeye mahkûm olacaktır.

İronik anlatımın en çok dikkat çektiği hikâyelerden biri de Keramet'tir. (Seyfettin, 2014, s. 359) Yarım saatten beri devam eden yangın karşısında itfaye erlerinin çabaları yeterli gelmemektedir, fakat mahalleli yangının biraz sonra söneceğinden emindir. Zira iki ev ileride "bir zat-1 şerif"in türbesi vardır. Bu esnada eski bir külhanbeyi olan Çiroz Ahmet talan peşindedir. Türbedeki şamdan ve el yazması Kuranı gözüne kestiren Çiroz Ahmet içeri girer. Fakat işler planladığı gibi gitmez ve alelacele kaçmak zorunda kalır.

\footnotetext{
2 Ömer Seyfettin'in karakterinde baskın bir unsur olan mizahla ilgili olarak bkz: Bayar, 2019, s. 114-116.

${ }^{3}$ Halk inancı kavramı sınılılıkları belirlenmiş ve henüz üzerinde ittifak edilmiş bir kavram değildir. Halk edebiyatı araştırmacıları ve din adamları arasında kavramsal çerçeve üzerinden tartışmalar devam etmektedir. Bize göre de "Batıl inanış" kavramı, halk inanışlarını tam olarak karşılayan bir ifade biçimi olmadığı için, çalışmamızda batıl inanış=hurafe şeklinde bir metodolojik yaklaşımı temel alacağız.

${ }^{4}$ Nazım Hikmet Polat'a göre bu sayı tam olarak 166'dür. (Bkz: Polat, 2007, s. 21)
} 
Tanınmamak için sandukayı yüklenir ve altına girerek dışarı firlar. Hırsızlığın farkına varamayan kalabalık için bu bir "keramet"tir. Türbe, evliyasını kaybetse de mahalledeki kutsiyetini sürdürmeye devam edecektir ve halk, hurafesinden vazgeçmeyecektir.

Perili Köşk'te, Sermet Bey nihayet aradığı kiralık meskeni bulmuş aydın bir tiptir. Nitekim “çocukları mektebe giderdi. Kızlarını büyük ticarethanelere kâtip diye yerleştirmişti. Karısı kız mekteplerinde piyano dersi verirdi." (Seyfettin, 2014, s. 271) Fakat bu köşkün dilden dile dolaşan bir kusuru vardır. Köşk, perilidir. Periler köşkte oturan her müsteciri bir zaman sonra rahatsız etmekte ve çıkmaya zorlamaktadır. Evin sahibi Hacı Niyazi Efendi, her gelen kiracı erken çıktığ için zarar etmektedir. Bu kez bir kontrat ister ve yüklüce bir parayı peşin alır. Kısa zaman sonra periler yine harekete geçer. Nitekim "burası eskiden kabristandır ve mutfağın olduğu yerde beş yüz senelik bir evliya yatmaktadır." Baştan beri söylentilere inanmayan Sermet Bey, bir ağaca saklanır ve periyi beklemeye başlar. Peri gelince üzerine atlar, örtüyü kaldırdıklarında karşılaştıkları sima, Sermet Bey hariç herkesi şok eder: Karşılarında evin sahibi Hacı Niyazi Efendi vardır. Yazara göre dindarlık hacılık vasfinda, şekil ve söylemlerde değil, ahlaka ve yaşantıya yansıdığ1 vakit muhterem bir şeydir.

Kurbağa Duası hikâyesi (Seyfettin, 2007, s. 132) İstanbul'a pek uzak olmayan bir kasabada öğretmenlik yapan bir muallimin muzip anısı şeklinde karşımıza çıkmaktadır. Muallim, diğer öğretmen arkadaşlarıyla Bektaşi tekkesine eğlenmeye gider. Oradakilerden biri de ulum-1 diniye hocası Bahir Efendi'dir. Eğlencenin bir yerinde ortadaki havuzda bulunan kurbağa sesleri herkesi rahatsız etmeye başlar. Durum dayanılmaz bir hâl alınca çözümü Bahir Hoca bulur. Usulca havuza yaklaşır ve kurbağalara bir şeyler fisıldar. Sesler anında kesilir. Duruma şahit olan herkes hocanın nefesinde keramet bulur. Oysa Bahir Efendi sadece nargilenin marpucunu sarkıtmıştır ve onu yılan zanneden kurbağalar korkup susmuştur. Bu hikâyede halkın nefese, üfürüğe itimadı üzerinden bir hiciv oluşturulmuştur.

Pireler hikâyesinde anlatıcı kahraman, "temizlik merakı delilik seviyesinde" olan Rose Mayer ile İzmir'de birlikte yaşayan mutlu bir adamdır. Köpekleri Koton da bu mutluluğa ortaktır. Günün birinde Koton $^{5}$ aniden rahatsızlanır. Ne kadar baytara götürseler de zavallı köpek bir türlü iyileşemez. Tavsiyeler üzerine gittikleri İtalyan baytar kendilerine köpeğin üzerine bir miktar pire bırakmalarını söyler ve arkalarında yarım yamalak Türkçesi ile söylenir: "Siz istersiniz muska... Siz istersiniz üfürük... Siz istersiniz ilaç." (Seyfettin, 2014, s. 380) İtalyan baytara göre hastalıkların evvela sebeplerini bulmak lazımdır. Zira pireler, köpek için faydalı bir mahlûktur. İtalyan sözlerine şöyle devam eder: Allah dünyada hiçbir hayvanı, hiçbir azayı vazifesiz yaratmadı. En fena hayvanların, en muzır mikropların bile vazifeleri vardır” Görüldüğü gibi önce Türkleri muskacilık ve üfürükçülükle suçlayan İtalyan, üstüne bir de iman ve hikmet dersi vermiştir. Neticede pek ikna olmasalar da bu öneriyi denemek zorunda kalan çiftimiz, sonunda köpeğin canlanıp ayağa kalktığını görür. Nihayet, her işi müspet ilimle yapmak gerekmektedir.

Asilzadeler (Seyfettin, 2007, s. 166) hikâyesinde falcllık meselesi ele alınmıştır. Ömer Seyfettin öykülerinde genellikle yaşlı ve eğitimsiz kimselerden oluşan falcılar uyanık kimselerdir, halkın cehaletinden ve umutlarından yararlanırlar. Bu hikâyede ise otuz sene evvel Tunus'ta dilencilik eden Salih Paşa, İstanbul'a döndükten sonra falcılık yapmış sonra da ilaç işine girerek saraydaki nüfuzlu kişilerin arasına karışmışır. Halkın umutlarını sömüren bir dolandırıcının saraya kadar uzanan kariyer hikâyesi eleştirel bir dille anlatılmıştır.

Ömer Seyfettin hikâyelerinde halkın dini duygularını sömüren üçkâğıtçı ve ahlaksız tiplere de yer verilmiştir. Birbirinin devam niteliğindeki iki öykünün ilki olan Külab’ta Mıstık ve Molla ismindeki iki dolandırıcının hikâyesi konu edilir. İki dolandırıcı da birbirini gözüne kestirmiş karşııındakini kandırmak için firsat kollamaktadır. Kırk beş yaşındaki Molla sade ramazanda ve üç aylarda değil, güya yılın yarısını oruç tutarak geçirirken; Mıstık "küçükken hafızlık çalıştı̆̆ından, ama hastalandığı için vazgeçtiğinden, babasının yirmi yedi defa hacca gittiğinden" (Seyfettin, 2017, s. 332) bahseden bir yalancidır. Nihayet Mistık kurduğu tuzağa kendisi düşmüş ve rezil olmuştur.

Mıstık tipi, Çakmak hikâyesinde de karşımıza çıkmaktadır. Makedonyalı dolandırıcının yanında bu kez yıllardan beri görmediği İboş vardır. İki eski dost oturup uzun uzun sohbet ederlerken bir ara Mıstık, İboş’un çakmağını çalar. İnkarlar, münakaşalar derken mesele mahkemeye intikal eder ve Mıstık "gayet soluk, lekeli bir yeşil çuha örtülmüş kürsüye yaklaşarak yeşil bir bohçaya sarılı kitaba elinin bütün kuvvetiyle basarak" (Seyfettin, 2017, s. 195) çakmağı çalmadığına yeminler savurmuştur. Mistık bu suretle

\footnotetext{
5 Alangu'nun verdiği bilgiye göre, Ömer Seyfettin'in köpeğinin adı da Koton'dur. Samur renginde, orta boylu, belli bir cinsi olamayan bu sokak köpeği olan Koton dişidir. (Bkz: Alangu 2010: 179).
} 
davayı kazanmıştır. Mistık, yalan yere yemin eden, Kuran'a el basarak adaleti ve toplumu aldatan bir düzenbazdır. Yazar, uyanık geçinen tamahkâr ve hileci tiplerin düştügü durumu ince alayla eleştirirken, din kisvesi alında dolap çevirenleri mizahî bir dille ifşa ederek "zekâsının hakkını" alarak rahatlar (Kılınç, 2008, s. 5). Fizilok (1984, s. 123) Mistık karakterinin yer aldığı her iki hikâyenin de birer halk hikâyesi olduğunu tespitini yapmıştır. Halkı dinle aldatmak mevzusu Pireler hikâyesinde de işlenmiş, muska ve üfürükçülük bir İtalyan baytarın ağzından lanetlenmiştir.

Yemin hikâyesinde yirmi sene evvelki bir hatırasını anlatan kahraman, "En büyük günahlar bir din, iman, terbiye, namus, nezaket perdesi altında hiç sezdirilmeden yapılır, masumluğun mukaddes füsunu asla kaybedilmezdi." (Seyfettin, 2014, s. 90) demektedir. Zira ölesiye sevdiği Matlube bir randevuevi işletmecisi bir kadının kızıdır. İsminin Hacıhanım olduğunu öğrendiğimiz kadın çok sofu görünümlüdür ve namaz, oruç, iman en meraklı olduğu konulardır. Anlatıcı genç, bir gün sevgilisi Matlube'nin eski belalısının Kur'an'a el basılarak evden uzaklaştırılmasına şahit olur. Öyküde basit bir kurguyla saf bir gencin üzerinden halkın din duygusuyla nasıl aldatıldığı vurgulanmıştır.

Ömer Seyfettin'in ironiyle ele aldığı halk inanışları bahsinde din adamlarını hiç ıskalamamıştır: Deve hikâyesinde aslen Çingene olan Mestan Ağa, değişmeye karar verir. Doğup büyüdüğü Edirne'yi terk ederek Çanakkale'ye gelir ve cambazlık yapmaya başlar. Bir çember sakal bırakıp başını sarıkla çevirir, adını da Abdülmennan olarak değiştirir. Anlatıcı ondaki değişimi şöyle ifade eder: "Atpazarında eşek alışverişinde herkes onu hacı zannediyordu. Çingeneliğini belli etmemek için daima taassup taslar, beş vakit namazını kalabalık camilerde kılar, ayakta besmelesiz su içmez, ezanı duyunca 'Aziz Allah, şefaat ya Resulallah' diye hemen sözünü keserdi.” (Seyfettin, 2014, s. 193) Mestan’ın bütün hülyası biraz para kazanıp Anadolu’ya yerleşmek ve orada beyaz bir Türk kızıyla evlenerek çingenelikten büsbütün kurtulmaktır. Bir gün camide vaaz eden imam deve binmenin tekinsizliğinden bahseder. Mestan A ğa tabiatındaki asiliğe ve cahil merakına teslim olduğu bir gün deveye biner. Çılgına dönen hayvan çevredeki tarlaları bozar, sırtındaki Mestan'ı da yere yapiştırır. Köylülerden sağlam bir sopa yedikten sonra Edirne'nin yolunu tutan Çingene, dindar numarası yapmanın cezasını bulmuştur.

Binecek Şey hikâyesinde tam anlamıyla miskin bir din adamı portresi çizilmiştir. Hikâyenin başında "kirli, yırtık yeniyle alnının terini silen" ve bedavaya yaşayacağı yeni yer arayan Derviş Hasan'ı görürüz. Otuz yıldır böyle asalak gibi yaşamaktadır. Yazar bu durumu "Her yerde ona yiyecek verirlerdi. Anadolu tekkelerinin kapıları ardına kadar açıktı. 'Huu' diye girer, isterse haftalarca, aylarca, ta canı sikılıncaya kalırdı" (Seyfettin, 2017, s. 163) diye anlatır. Sıcağın altında uzun ve çetin bir yolculuğa çıan Derviş o kadar yorgun ve bitkin kalmıştır ki artık tek istediği su ve bir binecektir. En sonunda bir grup yörükten sağlam bir dayak yer. "Allah'ın 'istenildiği gibi' değil, 'istediği gibi' vermesi en haklı hikmetidir" (Seyfettin, 2017, s. 168) ve Derviş Hasan nihayet bunu anlamıştır. Kilınç (2008, s. 1) bu hikâyenin temelinde bir halk anlatısı oluğunu belirtir.

Din adamlarındaki cehaletin en çarpıcı şekilde işlendiği hikâye, kanaatimizce Hatiften Bir Seda'dır. Fatih semtinde oturan Hacı İmameddin Efendi, tıpkı Türbe hikâyesindeki Şefika Molla gibi kendini evine kapamış, dünyayla ilgisini kesmiş bir din adamıdır. Yeşile boyanmış kapısının arkasında canlı bir evliya gibi yaşayan bu zat, nefsini canlandırmamak için zeytin, kuru incir, hurma ve bayat ekmekten başka şey ağzına götürmez. Ne var ki onun başı da kumarbaz, sarhoş ve mütecaviz oğlu Tahsin'le beladadır. Anlatıcıya göre, "ihtimal ki, Allah Taala Hacı İmameddin Efendi'yi bu fâni dünyada ağır bir imtihana çekiyordu." (Seyfettin, 2017, s. 341) Oğlu ile ilgilenmek, onu dinlemek ve dertleriyle meşgul olup onu kazanmak yerine durumu kabullenip kendini ibadete veren bu zat en sonunda altmış üç yaşını tamamlayınca bahçesinde kazdırdığ1 çukura inip "Yesevi gibi" çile hayatına başlamaya karar verir. Hikâyenin sonunda, gece karanlığında oğlunun bahçeden gelen sesini, gaipten gelen ruhani bir ses zannedip kendini aşağıya bırakarak ölür. Oysa sevgi fedakârlık isteyen bir şeydir, sevdiklerimiz için dua etmemiz yetmeyecek onlar için mücadele etmek gerekecektir.

Kadere tevekkül konusundaki yanlış algilamanın eleştirildiği bir diğer öykü de Tos?dur. Bu öyküde yedi ceddi hacı hoca, çok sofu bir kadın olan Fatma Hanım'la karşılaşıyoruz. Beyaz bir türbeye benzeyen evinde gece gündüz ibadetle meşgul olan bu kadının imtihanı ise azgın, huysuz ve münasebetsiz kocasıdır. Ne var ki Fatma Hanım bu durumu imtihan olarak kabul etmiş, durumun düzelmesi için Allah'a dua etmeyi bile onun işine karışmak olarak telakki etmiştir. Öyküde sabır ve tevekkül duygusunun dua etmeye bile mâni olduğu bu din anlayışı eleştirilir. Hikâyenin bir yerinde konu komşu cephedeki askerler için dua talep ettiğinde, Fatma Hanım korkmuş ve "Allah'ın işine karışlır mı, O ne yaparsa iyi yapar." demiştir. 
Fatma Hanım'a göre Allah gavurlarıla bizim terbiyemizi veriyordu. Zelzele, yangın, kıtlık, zulüm, muharebe, kolera, veba Allah'in en meşhur cezalarıydı. (Seyfettin, 2014, s. 185)

Ömer Seyfettin'in öyküleri arasında yobazlığın, miskinliğin, cehaletin en kuvvetli şekilde işlendiği ve halkın yaşamı düşünmeye ve sorgulamaya çağrıldığı eser, Beynamaそ, dır. "Az tamah çok ziyan getirir." başlığıyla sunulan hikâyede, Hacı İmam ismiyle bilinen din adamının önderliğinde bir köyün nasıl tembelliğe sürüklendiği anlatılmıştır. On yedi yıldır bu köyde yaşayan Hacı İmam, yediden yetmişe herkesi cemaatle namaza alışırmış, köyde abdest, namaz oruç, farz, vacip münakaşalarından başka laf edilemez olmuştur. Onun tatlı ve tesirli nasihatleriyle, ruhani vaatleriyle köyün hayatı, manzarası, hasılı her şeyi değişmiştir: "Günün en aşağı yedi saatini abdest almakla, namaz kılmakla, camide aşir, kahvede hususi vaaz dilemekle geçiren köylüler 'ekim biçim’ işlerini tamamıyla kadınlara bırakmıştı. Bağlarda bahçelerde hiçbir erkek görülmezdi." (Seyfettin, 2014, s. 247) Yaşananlara tepki gösteren tek kişi ise köyün beynamazı Gâvur Ali'dir. "Ah bire, keratalar bire! Karılarınız olmasa açlıktan gebereceksiniz" diyen Gavur Ali, yaşanan trajedinin farkında olan tek kişidir. Yine bir keresinde hastalık kapan koyunlar teker teker ölürken, nedenini öğrenip tedbir almak yerine, mevlit ve hatime başvurulmuştur. Hikâye boyunca köylülerin içinde bulunduğu gülünç durum onun muhalif kimliğiyle açığa çıkartılır.

Tubaf Bir Zulüm hikâyesinde Gospodin'in "Türklerde hiçbir şey, hiçbir fikir, hiçbir ideal yoktur. Yalnız bir şey vardır: Taassup!” (Seyfettin, 2014, s. 76) şeklindeki tespiti oldukça manidardır. Hikâyenin merkezi kahramanının bu noktada hiçbir itirazı olamamış, susup kalmıştır.

Havyar hikâyesinde Hamdune Hanım şeyhülislam kocasını kaybetmiş yirmi yıldır dul yaşamaktadır. Yaşı altmışı geçen bu kadın, pembe ile beyaz arası bir renktedir ve "kendi gibi beyaz, tombul, yetişmiş, tam kıvamına gelmiş bir tanecik kızcağızı" (Seyfettin, 2014, s. 371) vardır. Beyazlı̆g güzelliği kadar meşhur olan bu kıza, komşuları "Kaymak Hanım” demektedir. Hamama girdi mi bütün kadınlar ondaki göz kamaştırıcı beyazlığa şaşırır, "tüh tüh, yaradana, maşallah" derler ve nazar değecek korkusuyla ona bakamazlar. Nihayet Hamdune Hanım nazarlardan sakındığı, kimselere layık bulamadığı kızına layık bir "sofu" damat bulur. Kendisi pek dindar olmasa da, dindar kişilerden zarar gelmeyeceğini inanmaktadır. Beş vakit namazın arasına nafileleri sokuşturan, üç ayları bozmadan tutan bu damat, hikâyenin sonunda yoldan çıar; "kaymak" gibi hanımını, evin Arap hizmetçisiyle aldatır. Kısacası damadın canı siyah "havyar" çekmiştir. Hamdune Hanım, damat adaylarında karakter ve asalet aramak yerine, sade sofuluk aramanın bedelini hem kendisine hem de zavall kızcağızına ödetmiştir.

Eleğimsağma ${ }^{6}$ hikâyesinde Ayşe isminde bir genç kızın yaşadığı drama tanık olmaktayız. Kuvvetli bir kız olduğu için ona çevresindekiler "Pehlivan Ayşe" demektedir. Çünkü o "erkek çocukları gibi ata binmesini, silah atmasını, güreşmesini, birdir bir, esir almaca oynamasını çok sevmektedir." (Seyfettin, 2017, s. 80) Ne var ki artık bunlara veda etme zamanı gelmiştir. Köyün imamına göre Ayşe artık büyümüştür ve örtüye girmesi gerekmektedir. Ayşe bir gün renklerinin bütün ihtişamıyla gökkuşağı görür ve içine dalar. Yerler çamur içindedir, Ayşe orada bayllır. Saatlerce anası babası, köylüleri onu ararlar ve en sonunda o çamurun içinde zavallı kızcağızı bulurlar. İki lafının birinde caiz değil diyerek nefret oluşturan köyün imamı yine "örtüye koyun onu, örtüye" derken "zavallı Ayşe hiç sesini çıkaramıyor, utancından yerlerin dibine geçiyor, bastığı çamurlara bakarak, bütün göğsünü sarsan derin hıçkırıklarla hüngür hüngür ağlamaktadır. (Seyfettin, 2017, s. 87) Hikâyede yobaz bir imamın, gelişim çağında ve henüz on yaşındaki bir kız çocuğunun din adına ruhunda açacağı yaralara dikkat çekilmiştir.

Ömer Seyfettin, adını "bilgisiz, cahil ve kaba" anlamlarına gelen Farsça bir isimden alan Nadan adlı hikâyesinin tanıtım başlığında "Nadan ile sohbet etmek güçtür bilene; çünkü nadan ne gelirse, söyler diline." (Seyfettin, 2017, s. 382) atasözüne yer vermiştir. Bu tavriyla yazar, cehaletten duyduğu rahatsızlğın ne denli büyük boyutlarda olduğunu vurgulamaktadır. Kendinden önceki Ahmet Mithat Efendi'nin sıklıkla, Sami Paşazâde'nin kısmen işlediği cehalet konusu, Meşrutiyet dönemi yazarı olan Ömer Seyfettin'in toplumsal içerikli hikâyelerinde temel mevzudur. Cehalet onun eserlerinde yine gülünç unsuruyla birlikte açığa çıarılmış, ironik bir dille anlatılmıştır.

Selahattin Eyyubi döneminde, Dımışk şehrinde geçen Büyücü hikâyesine Doğan Bey üç erkek kardeşi cephede asker olan, kendisi ise kimya ve hendese ile meşgul olan bir ilim adamıdır. Evinden dışarı pek çımayan ve içeride ilmi çalışmalarla meşgul olan Doğan Bey, bir süre sonra meraklı ve cahil halkın

\footnotetext{
6 Arapça “alâimsemâ" kelimesinden türemiş ve halk ağzına "eleğimsağma” şekline oturmuş olan bu kelime gökkuşağ1 anlamındadır. Anadolu yüzyıllardan beri var olan yaygın bir inanca göre, erkek olmaya özenenler onun altından geçerek muratlarına ermektedirler. (Bkz: Eyüboğlu 1998: 132)
} 
tepkisini çekmeye başlar. Anlatıcı, bu durumu "Halkın mahiyetini bilmediği şeye kin bağlaması tabii idi." (Seyfettin, 2017, s. 229) tespitiyle açıklar. Artık halk şehirdeki her uğursuzluğu ona bağlamaya başlarlar, onlara göre kuraklığın, yangınların, cinayetlerin sebebi hep büyücü Doğan'dır. Bir süre sonra Doğan'ı sultana şikâyet ederler. Oysa hikâyenin ilerleyen kısımlarında Doğan Beyin bir buluşu Akka savunmasında kritik bir fayda gösterecek ve böylece Kudüs ve Suriye'nin istikbali muhafaza edilecektir.

Müjde hikâyesinde ise konu Çanakkale Savaşları sırasında harbe iştirak eden askerler arasında geçmektedir. Hemen hepsi eğitimli kimselerden oluşan bir gurup asker, gecenin zifiri karanlığında siperlere intikal etmektedir. Derken denizin ortasında bir parlaklık peyda olur, gökyüzüne baktıklarında ise bir ziya görünmektedir. Pek çoğu şair olan genç askerler orada "fethün karib" yazdığını iddia eder. Bu "müjde"ye inananlar arasında kafilenin genç doktoru da bulunmaktadır. "Hepsi Allah'ın işaretini gören müminler gibi dalgın, müphem bir vecd içindedir." (Seyfettin, 2017, s. 349) Oysa gördükleri şey yalnızca "hacer-i semavî", yani göktaşıdır.

Bilgisizliğin, tecrübesizliğin ironiyle ele alındığı ve "Bir genç kızın defterinden kopya edilmiştir." notuyla verilen Horoz ve Dünyanın Nizamı hikâyeleri birbirini devamı niteliğindedir. Her ikisinde de hikâyenin kahramanı bir genç kızdır.

Horoz öyküsünde otoriter babasının köşkü idare etme biçimiyle horozun kümesi idare etme biçimi arasında bağ kuran genç kız, âdeta erkek egemenliğine savaş açar ve kümesteki horozu nefretle öldürür. Kibir ve güç abidesi horozun ölümüyle ezilen tavukların intikamı alınmıştır. Tavuklar bundan böyle huzur içinde yaşayabileceklerdir. Tavuklar ile kadınlar arasında bağ kuran kız "Ah bu tavuklar... Dünyada bunlar kadar sevimli, bunlar kadar kendi hallerinde, bunlar kadar saf, bunlar kadar masum bir mahluk var midir? Hayatları bütün bir vazife, bütün bir fedakârlık destanıdır.” (Seyfettin, 2007, s. 102) diye düşünür. Kadınlı̆ğ yüceltir; evlenmeye, bir erkeğin egemenliği altına girmeye gerek olmadığını düşünür.

Horoz hikâyesinin devamı olan Dünyann Niæaminda, müteveffa horoz genç kızın rüyasına girer. Niyeti hesap sormaktan ziyade, genç kızın, işlediği cinayetin sonuçlarıyla yüzleşmesini sağlamaktır. Nitekim horozun ölümünden kısa bir süre sonra kümeste işler karışmışır. Uyandığında balkondan çıkıp dalgın dalgın bahçenin perişan hâlini seyreder. Bahçe harabe haline gelmiştir ve tavuklar yumurtayı kesmiş, duvar diplerinde kötürüm gibi uyuklamaktadır. Uyanıkken de dövüşmekte, birbirinin gözünü oymaktadır. Demek ki horoz kümes için fevkalade önemlidir. Horoz hikâyesindeki fikirlerini cahilce bulan genç kız, ani bir kararla evdekilere evlenmeye karar verdiğini bildirir, zira "Dünya nizamını bozmaya gelmez". (Seyfettin, 2007, s. 113)

Anlatıcı genç kızın dikkat ve ironi yüklü anlatımıyla okuduğumuz, kadın-erkek ilişkileri bağlamında evlilik kurumunun sorgulandığı bu iki hikâyeden anlaşılmaktadır ki; tecrübe, önemli ve önyargı ise çok kötü bir şeydir. Kadın ve erkek, her ikisi de muhterem varlıklardır ve birbirini tamamlamak durumundadırlar.

\section{Sonuç}

Ömer Seyfettin (1884-1920), Meşrutiyet Döneminde eserler vermiş bir hikâyeci, şair, düşünür ve muallimdir. Yüz altmış dokuz hikâyesi ile Türk okurunu millî anlamda hikâye ile tanıştıran odur. Bu hikâyelerindeki gücüyle kendi devri ile Cumhuriyet devri arasında esaslı bir geçiş dönemi teşkil etmiştir.

Çocukluk ve gençlik yıllarında askeri eğitim almış daha sonra Anadolu ve Balkanlarda görev yapmıştır. Dolayısıyla savaşlar ve tarih onun hikâyelerinde ana iskeleti oluşturmuştur. Meslek hayatı boyunca cephe gerisinde edindiği gözlem ve intibalar ise onun sanat hayatının bir başka cephesini teşkil eden toplumsal hikâyeciliğini ortaya çıkarmıştır.

Yakın sanatçı dostlarının kaleme aldığı makale ve anılarında aktardığı bilgilere göre, Ömer Seyfettin şahsi hayatında mizaha yatkın bir kişidir, mübalağa ve tariz onun mizacının en dikkat çeken yönleridir. Çevresinde gördüğü saçma olaylara ve münasebetsiz kişilere tahammül etmeye mâni, güçlü bir vicdan ve cesarete sahip olan yazar, toplumsal konuları ele aldığı hikâyelerinde bu yönleriyle dikkat çeker. Özellikle halk inançlarına değindiği hikâyelerinde ortaya bir çıkan bu husus, bir gerilime dönüşecek sanıldığı anda, aniden parlak bir zekâ ve munis bir kalem ustalığıyla ironiye dönüşüvermektedir.

\footnotetext{
7 "Fetih yakındır" anlamına gelen bu ifade, "Ve kendiniz için bir lütuf daha var: Allah’tan bir yardım ve yakın bir fetih. Müminleri müjdele." mealindeki ayete telmihtir. (Bkz: Saff Suresi, 13. Kur'an)
} 
İroni, en basit tarifiyle beklenen ile gerçekte olan arasındaki fark1 açığa çıkartma sanatıdır. Hayatın içindeki çelişki ve çatışmaları gülünç olana dönüştürmektedir. Sanat değeri taşıyan bir yazıyı, sıradan bir yazıdan ayıran şekle ve/veya muhtevaya ilişkin farklar vardır. Bunlardan bir tanesi de hiç kuşkusuz ironik anlatımdır.

Ömer Seyfettin'in ironiyi kullandığ1 ve sosyal meseleleri ele aldığı başka hikâyeleri de elbette mevcuttur. Fakat biz bu çalışmamızda hususen cehaletin halk inanışlarındaki tezahürünü merkeze aldık. $\mathrm{Bu}$ anlamda incelediğimiz hikâye sayısı yirmi birdir. Bunların tamamı Hülya Argunşah'n derlediği külliyatın son üç cildinde yer alan hikâyelerdir. Ekseriyeti Balkan Savaşları'nı, yazarın Balkanlarda geçen çocukluk anılarını ve Türklük duygusunu işlediği hikâyelerinden oluşan ilk ciltte konumuzla ilgili bir öyküye rastlayamadik. İncelediğimiz Eleğimsağma, Binecek Şey, Cakmak, Büyücü, Hatiften Bir Seda, Müje, Yemin, Tos!, Deve, Türbe, Beynamaz, Perili Köșk, Yalmz Efe, Keramet, Havyar, Pireler, Horoz, Dünyanm Nižamı, Kurbağa Duası ve Asilz̧adeler adlarındaki hikâyelerde dört ana muhteva ile karşılaştık. Bunlar:

1. Türbe ve türbe etrafinda gelişen keramet algisı.

2. Peri ve cinlerden oluşan metafizik evren.

3. Nefes-üfürük, nazar ve fal bakma biçiminde ortaya çıkan âdet ve inanışlar.

4. Halkın din duygusunu istismar eden din adamları veya dolandırıcılar ve bunların müşteri kitlesi olarak cahil halk.

5. Tevekkülü tembellik zannederek miskin bir hayat yaşayan din adamları.

6. Öğrenmeye, değişime kendini kapamış peşin hükümlü cahil halk.

Hikâyelerde ironinin kullanımıyla ilgili tespitlerimiz şu şekildedir:

1. Ömer Seyfettin, hikâyelerinde umumiyetle olay ironisi kullanmıştır. Bu tabii karşılanması gereken bir sonuçtur. Zira Ömer Seyfettin vak’a hikâyecisidir. ${ }^{8}$

2. Hikâyelerinde ironiyi sağlayan ana unsur cehalettir. Buna ilaveten hayatın tesadüfleri ve çelişkilerin de etkili bir unsur olduğu görülmektedir.

3. Ömer Seyfettin ironiyi yaptıktan sonra bir kenara çekilmez, genellikle oradan bir sonuç çıkarır. Bazen, Külah ve Cakmak hikâyelerinde olduğu gibi, aynı konuyu tekrar tekrar gündeme getirir. Horoz ve devam hikâyesi Dünyanı Niz̧ami'ndaki gibi yeni bakış açılarını da gündeme taşır, bir tartışma ortamı yaratmaktan çekinmez. Örgen'in de ifade ettiğgi gibi (2009: 259) ironinin karşı olma tavrı, onda sorumluluktan kaçmak anlamında değildir.

4. İroniden sonra okuyucuda kalan, acı bir tebessüm ve sorgulama isteğidir.

İroni, Türk edebiyatında Karagöz ve Hacivat temsillerinden, Nasrettin Hoca güldürülerinden itibaren görmeye alış1k olduğumuz bir anlatım türüdür. Modern dönemlere geldiğimizde ilk olarak Ahmet Mithat Efendi’nin hikâyelerinde görmeye başladığımız bu hususiyet, ondan itibaren Ömer Seyfettin'le altın dönemini yaşamış, oradan Hüseyin Rahmi’ye, Haldun Taner'e ve Aziz Nesin'e uzanan bir çizgi halinde başarıyla devam etmiştir. Hasıll, Türk okuru ve toplumu bu anlatım türünü pek sevmiş, yüceltip el üstünde tutmuştur.

\section{Etik Beyan}

“Ömer Seyfettin'in Hikâyelerinde İroni İle İnşa Edilen Eleștirel Söylem: Cehalete Dayanan Halk İnanşslarn” başlıklı çalısmanın yazım sürecinde bilimsel kurallara, etik ve alıntı kurallarına uyulmuş, toplanan veriler üzerinde herhangi bir tahrifat yapılmamış ve bu çalışma herhangi başka bir akademik yayın ortamına değerlendirme için gönderilmemiştir. Bu araştırma doküman incelemesine dayalı olarak yapıldığından etik kurul kararı zorunluluğu bulunmamaktadır.

\section{Teşekkür}

Bu makaleyi akademik çalışmalarımda her zaman desteğini gördüğüm İbrahim Dilmen ve şair A Samet Atılgan'a armağan ediyorum. Bahtları da kalpleri gibi temiz olsun. Onlar benim eskiden öğrencimdi, şimdi ise meslektaşım ve arkadaşım.

\footnotetext{
${ }^{8}$ Mehmet Mehdi Ergüzel konuyla ilgili yakın zamanda çıkan bir yazısında Ömer Seyfettin’in eserlerinden 11330 kelimelik söz dağarcığı ortaya çıktığını, bunların \%35 nispetle somut kelimeler ve \%22’lik oranda fillerden oluștuğunu belirtmektedir. Ergüzel'e göre, Ömer Seyfettin’in hikâyeci üslûbu, üçte iki oranında somuta ve harekete açılırken, düşünce üslûbu aynı ölçüde soyuta ve düşünceye kapanmaktadır. (Bkz: Ergüzel 2020)
} 


\section{Kaynakça}

Alangu, T. (2010). Ömer Seyfettin ülkü̈ü bir yazarn romanı. İstanbul: YKY.

Banarli, N. S. (1998). Resimli Türk edebiyatı taribi C. 2. İstanbul: MEB Yayınları.

Baş, M. K. (2019). Ömer Seyfettin kurgusunda ironi ile inşa edilen ahlaki söylem: Zeytin Ekmek hikâyesi örneği. Hece, 265, 202-209.

Bayar, S. Ö. (2019). Ömer Seyfettin öykülerinde tenkit aracı olarak mizah, Ömer Seyfettin Özel Sayıs1, Hece, 265, 114116.

Birinci, E. (2002). Ömer Seyfettin'in bikâyelerinde Türk toplumu (Doktora Tezi). Sakarya Üniversitesi Sosyal Bilimler Enstitüsü, Sakarya.

Cevdet K. (2016). Türk edebiyatında bikâye ve roman. İstanbul: Kap1 Yayınları.

Çetişli, İ. (2012). İkinci Meşrutiyet dönemi Türk edebiyatı. Ankara: Akçağ Yayınları.

Enginün, İ. (2006). Yeni Türk edebiyatı Tanzimat'tan Cumburiyete (1839-1923). İstanbul: Dergâh Yayınlar1.

Enginün, İ. (2012). "Sunuş" kısmı, Ömer Seyfettin, bütün eserleri, bikâyeler 1 (Haz: H. Argunşah). İstanbul: Dergâh Yayınları.

Ergüzel, M. M. (28.04.2020). Ziya Gökalp ve Ömer Seyfettin’in söz varlı̆̆1, 59haber, erişim: 25.06.2020.

Eyüboğlu, İ. Z. (1998). Anadolu inançlar. İstanbul: Toplumsal Dönüşüm Yayınları.

Filizok, R. (1984). Ömer Seyfeddin'in eserlerinde halk edebiyat1 tesirleri. Doğumunun 100. Yalında Ömer Seyfeddin. İstanbul: Marmara Üniversitesi Fen Edebiyat Fakültesi Yayınları.

Güneş, M. (2011). Yüzyılın başlarında Balkanlardaki siyasî ve etnik çatışmaların Ömer Seyfettin'in hikâyelerine yansıması. TÜBAR, 29, 163-187.

Gürbüz, H. (2000). Sosyal meseleler açısından Ömer Seyfettin'in hikâyeleri. Hece Dergisi, 46/47, 284-297.

Kılınç, A. (2007). Metinlerarası ilişkiler bağlamında Ömer Seyfettin’in halk anlatı kaynaklı hikâyeleri. I. Dünden Bugüne Ömer Seyfettin Sempozyumu. İstanbul: Gönen Belediyesi Kültür Yayınları.

Kılınç, A. (2008). Mizahta rahatlama kuramına göre Ömer Seyfettin'in halk anlatı kaynaklı hikâyelerinde mizah. II. Dünden Bugüne Ömer Seyfettin Sempozyumu. İstanbul: Gönen Belediyesi Kültür Yayınları.

Narl, M. (2007). Ömer Seyfettin'den Cemal Şakar'a öykü ve ironi. İmi Araștırmalar, 24, 103-115.

Okay, O. (1992). Yeni Türk şiiri, Türk Dili Dergisi-Türk siïr Özel Sayısı-IV. Ankara: TDK Yayınlanı.

Örgen, E. (2009). Ömer Seyfettin öykülerinin yapısında ve dilinde ironi. Türk Yurdu, 259, 73-81.

Sevük, İ H. (1935). Edebî yeniliğimiz. İstanbul: Remzi Kitabevi.

Polat, N H. (2007). Ömer Seyfettin. İslam Ansiklopedisi C. 34. İstanbul: Türkiye Diyanet Vakf1 Yayınları.

Polat, N H. (2019). Ömer Seyfettin bütün bikâyeleri. İstanbul: YKY.

Seyfettin, Ö. (2007). Bütün eserleri, bikâyeler 4 (Haz: H. Argunşah). İstanbul: Dergâh Yayınları.

Seyfettin, Ö. (2012). Bütün eserleri, bikâyeler 1 (Haz: H. Argunşah). İstanbul: Dergâh Yayınlar1.

Seyfettin, Ö. (2014). Bütün eserleri, bikâyeler 3 (Haz: H. Argunşah). İstanbul: Dergâh Yayınları.

Seyfettin, Ö. (2017). Bütün eserleri, hikâyeler 2 (Haz: H. Argunşah). İstanbul: Dergâh Yayınları.

Tuğluk, A. (2017). İroni nedir. İdil, 29, 441-465.

Tunaya, T Z. (1998). Hürriyetin ilânı. İstanbul: Cumhuriyet Yayınları.

Uyguner, M. (1990). Ömer Seyfettin, yaşamı-sanatı-yapıtlarından seçmeler. Ankara: Bilgi Yayınevi.

Ünaydın, R E. (2010). Diyorlar ki. İstanbul: Tablet Kitabevi.

Yöntem, A C. (1993). Ömer Seyfettin hayat, karakteri, edebiyat, ideali ve iserlerinden numuneler. İstanbul: Remzi Kitabevi.

Yöntem, A C. (1995). Prof. Ali Canip Yöntem’in yeni Türk edebiyat üzerine makaleleri (Haz: A. Sevgi ve M. Özcan). Konya: Sözler Basım Yayım.

\section{EXTENDED ABSTRACT}

Ömer Seyfettin is a storyteller, poet, thinker and scholar who made works during the Constitutional Era. Please write one hundred and sixty nine stories, beautiful poetry and many articles. He also wrote theater texts. After being dismissed from the military, he also taught some teaching. It is he who introduces the Turkish reader to the real use story with a hundred and sixty-nine stories. It constitutes a substantial transition period between the Republican era.

It is for military education in childhood and youth. Later, he served in Anatolia and the Balkans, in Izmir, Thessaloniki and Macedonia. Here is the main skeleton in his stories of wars and history. In these stories, social life such as social life, neighborhoods, bazaar markets, houses, men and women, family life, child discipline will also be included in Romanian before the war. In its historical stories, there are definitely stories in the past in your work. Due to the current, historical issues were also covered. Observations and adaptations that he gained behind the frontline throughout his professional life emerged from social stories that constitute another aspect of his art life.

Ömer Seyfettin is a person who is prone to humor in his personal life, exemption and style are the most remarkable aspects of his temperament. The writer, who is trying to endure the absurd events and 
incongruous people he sees around him, has a strong, strong conscience and courage. Especially the issues that arise in his stories, which he touches on folk beliefs, turn into irony with the skill of a star that will turn into a tension and suddenly a brilliant intelligence and a unique pen.

The irony is the art of revealing the difference between what is expected and what is actually in its simplest description. It turns the contradictions and conflicts in life into a ridiculous one. There are differences in the shape and / or content that distinguishes a piece of art value from an ordinary one. One of them is undoubtedly ironic expression.

Irony is a type of expression that we are used to seeing from Karagöz and Hacivat performances and Nasrettin Hodja laughs in Turkish literature. At least it is possible to talk about a past dating back to the Seljuk period. When we go back to the past, we come across names such as satirical poetry, satire and grinding. In classical poetry, the satirical poems of Nef are famous. He is a poet who lost his life while trying to satire. When we came to the modern times, this feature, which we first started to see in the stories of Ahmet Mithat Efendi, had a golden period with Ömer Seyfettin, and continued successfully as a line extending from there to Hüseyin Rahmi, Haldun Taner and Aziz Nesin. Hasti, Turkish readers and society loved this narrative genre very much, glorified and kept it on hand.

According to Ömer Seyfettin, another characteristic of religion is that it organizes the individual and social life according to the good, the right and the beautiful. In terms of religion, it has a function that activates the mind and conscience, focuses science and envisages effort and work. However, the society observed by the author is far from them. The religion generally perceived by the society is a religion that is stuck in the quagmire of ignorance and away from science and reason. The society, where the trust of the trust is flawed, leads a delicate life in a passive religion, based only on prayer and worship. There is a riot in all of them in Ömer Seyfettin's narrative. The religion he understands is active and decisive. It is a social training tool, a source of motivation that will lead to the construction of the nation and the liberation of the state.

There are of course other stories where Ömer Seyfettin used irony and other social issues. But in this study, we centered the manifestation of ignorance on public beliefs. In this sense, the number of stories we examine is twenty one. These are all stories in the last three volumes of the collection compiled by Hülya Argunşah. We could not find a story about our subject in the first volume, which consists of stories of the Balkan Wars mostly, the author's memories of childhood and the sense of Turkishness in the Balkans. Some of the stories we have examined are: Elimsagma, Thing to Ride, Lighter, Magician, A Seda from the Calligrapher, Muje, Oath, Tos!, Camel, Mausoleum, Beymaz, Haunted Mansion, Lonely Efe, Miracle, Caviar, Fleas, Rooster, Order of the World, Frog's Prayer and Noblemen are their stories. In these stories we examined, we encountered four main ingredients. These are the perception of migration developed around the mausoleum and the mausoleum, the metaphysical universe consisting of fairy and jinn, the breath-blow, the evil eye and fortune-telling, the clergy or the scam people who exploit the religious sense of the people, and the ignorant people as a customer mass clerical people who have distanced themselves from learning and developing themselves, who have made a long distance and living a healthy life. 